\title{
THE TYPES AND IMPACTS OF BULLYING ON TAYLOR HILLRIDGE IN CYBERBULLY MOVIE
}

\author{
Nada Putri Sakinah ${ }^{1}$, Anita ${ }^{2}$ \\ ${ }^{12}$ Department of English Literature, Faculty of Letters and Cultures Gunadarma University \\ Jl. Margonda Raya No.100 Depok 16424, Jawa Barat
}

Corresponding Author(S): nadaputri0599@gmail.com,poponitalovely@gmail.com

\begin{abstract}
:
This research is about the types and impacts of bullying on Taylor Hillridge in Cyberbully movie. The aims of this research are: (1) To find out the types of bullying that the character Taylor Hillridge receives in Cyberbully movie. (2) To find out the impacts of bullying that the character Taylor Hillridge suffers in Cyberbully movie. Researcher used descriptive qualitative method. The result of this research for types of bullying researcher found 6 data of verbal bullying, 2 data of relational bullying, 10 data of cyber bullying. However, for the result of this research for the impacts of bullying researcher found, 1 datum of effects on feelings and behavior, 1 datum of academic impact, 1 datum of psychological impact.
\end{abstract}

Keywords:

\author{
types of bullying, \\ impacts of bullying, \\ Cyberbully movie
}

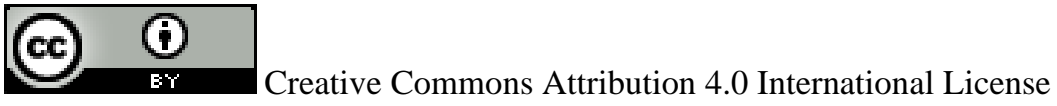

\section{INTRODUCTION}

Mostly, bullies are a huge and strong child or student, although they can also be small or middle in size, but they have considerable psychological dominance among their friends and have more power than the victims of bullying (SEJIWA, 2008). The victim of bullying are powerless to fight back because they believe they lack the strength. It's because most bullies aren't just one person, but more than 1 person. That's why victims of bullying are afraid to fight back with them. According to (Priyatna, 2010) the impacts of bullying is very dangerous for victims of bullying, can causes anxiety, depression, loneliness, suicide and so on. It is better for us to give education to the society, especially student, before the impact of bullying appears. With this education, it will be possible to inform society or students about the impacts of bullying and how to avoid to becoming bullies.

According to (Buckie, 2013) bullying occurs when someone repeatedly tries to hurt another person's body, feelings, self-esteem, reputation, or property. So, bullying is negative action that is carried out continuously from the bullies to the victim of bullying which can make the victim of bullying feel uncomfortable. According to (Wiyani, 2014) Some people may state that bullying behavior is trivial or normal in everyday life, but the fact is that bullying behavior is "learned behavior" because humans are not born to be 
bullies and annoy weaker people. This means that some people do not understand about bullying and the impact of bullying, because they normalizing bullying and they make bullying something normal. Even though bullying is a negative action that should be prevented, so that there are no more victims of bullying. We are not only help victims of bullying, but we also have to provide education to the bullies, so that they realize that bullying is something wrong and that it is not good.

There are four types of bullying according to (Coloroso, 2007). The first one is Physical Bullying. Physical oppression is the most visible and most identifiable bullying type among other forms of oppression. This bullying involves to physical contact "Physical oppression is striking, strangling, nudging, punching, kicking biting, crawling, scratching and spitting on the oppressed child to painful position, and destroying the clothes and belongings of the oppressed child". The type attack of the strong and mature oppressor is more dangerous, even if it is not meant to seriously harm. The second one is Verbal Bullying. Verbal bullying is putting that person down constantly with what you say for your own satisfaction. Verbal abuse is the most common form of oppression used by both girls and boys, "Verbal abuse is easy to do and can be whispered in front of adults and peers, undetected. Verbal oppression can be a nickname joking, reproach, tease someone, cruel criticism, humiliation, and nuanced statements of a sexual solicitation or sexual harassment". In addition, verbal repression could be the expropriation of money or things, spreading someone's belonging, rude phones, intimidating emails, letters, containing threats of violence, false accusations, and gossiping. The third one is Relational Bullying. This type is the most difficult to detect from the outside. "Relational oppression is a systematic attenuation of the victim's self-esteem through neglect, exclusion, or avoidance". The child being gossiped will probably not hear the gossip, but will still encounter the effect. Relational oppression can be used to alienate or reject a friend or deliberately aimed at destroying friendships. "This behavior can include hidden attitudes such us aggressive views, eye glances, heaves, shuddering, shoulders, scorn, sneered laughter, and harsh body language". The fourth is Cyber Bullying. This is the latest form of bullying because of the growing technology, internet and social media. In essence is the victim continues to get negative messages from the bullying offenders either from text, messages on the internet and other social media. "The form such as send a painful message or use a picture, leave voicemail messages cruel, call continuously without stopping, but silent calls, creating an embarrassing website for the victim, the victim is avoided or shunned from the chat room and others, happy slapping is a video containing where the victim was humiliated or bullied and the disseminated". These kinds of bullying surely give impact to the victims. The victims of bullies usually suffer mental issues because of bullying.

Impacts of Bullying According to (Buckie, 2013) impacts of bullying consist of two; The first is Effects on feelings and behavior. Bullying greatly affects the psychological state of someone who are bullied such as: "anxiety, depression, loneliness, low self-esteem. low marks, harming themselves. The last is Effects on adult behavior and relationships. Bullying can lead to serious problems in adulthood. "Bullying has also been found to lead to these behaviors in adulthood such as: sexual harassment, workplace harassment. spousal, child and elder abuse". Meanwhile SEJIWA.org, stated that the impacts of bullying are divided into three, namely: Academic Impact, this refers to the impact that affects the victim's academic activities and achievements, such as: "Poor learning achievement, difficult concentration in learning, skipping school or quitting until school 
phobia". Social Impact, this refers to social life of someone and how to socialize and adapt each other, for example: "Shy, isolated, passive, not confident and difficult to get along". Psychological Impact, this refers to bad mental condition of someone who get bullied, such as: "moody, depressed, revenge, eager to escape even suicide".

The aims of the researcher want to choose the topics of types of bullying and the impacts of bullying are because researchers want to tell the readers what types of bullying is happening around us and the impacts of bullying on someone. So that anyone who reads this research will not become a bullies and of course can be more concerned, if someone is a victim of bullying. The researcher choses the Cyberbully movie because there are many examples of types of bullying cases such as verbal bullying, relational bullying, cyberbullying which can tell the readers to be more careful in their daily lives and there are also the impacts of bullying until the main character wants to end his life, which will be discussed in this research.

This research use Coloroso's theory for analyze the types of bullying. However, for the impacts of bullying, the researcher use SEJIWA's theory and Buckie's theory. From the identification of problem of the research, the scope of the research is only discusses and focuses on types of bullying and impacts of bullying. The researcher only analyzes and explains about sentences, dialogue, scenes that contain types of bullying and impacts of bullying in Cyberbully movie.

\section{METHOD}

This research uses a descriptive qualitative method. Qualitative methodology as a research procedure that produces descriptive data in the form of written or oral words from people and observed behavior (Bogdan \& Taylor, 1975). It is means that qualitative is a research procedure that involves observing, interpreting, and reporting descriptive research results. This method describes about the types of bullying and the impacts of bullying that the character Taylor Hillridge received in Cyberbully movie. The data of the research is sentences, dialogue and scene that shows the types of bullying in Cyberbully movie.

Technique of collecting data are one of the ways taken by researchers to obtain data. The data collection techniques in conducting this research are watching Cyberbully movie and taking a note every types of bullying and the impacts of bullying in the form of text or dialogue or scene that contained in the movie Cyberbully. These are technique of analyze data the types of bullying in Cyberbully movie are classifying the data based on classification of the types of bullying and the impacts of bullying, analyzing the classified data based on the theory that researcher use and making conclusion based on the analysis on the data.

\section{RESULTS AND DISCUSSION Result}

The result of this research for types of bullying researcher found 6 data of verbal bullying, 2 data of relational bullying, 10 data of cyber bullying. However, for the result of this research for the impacts of bullying researcher found, 1 datum of effects on feelings and behavior, 1 datum of academic impact, 1 datum of psychological impact as described in the table below: 


\begin{tabular}{cclc}
\hline No. & Types of Bullying & \multicolumn{1}{c}{ Example } & Amount \\
\hline 1. & Verbal Bullying & - Nickname Joking & 6 \\
& & - Humiliation \\
& & - False Accusation \\
& & - Sneered Laughter \\
2. & Relational Bullying & - Aggressive Views & 2 \\
& & - Social Media Bullying & 10 \\
3. & Cyber Bullying & Total & $\mathbf{1 8}$ \\
\hline
\end{tabular}

Table 1 Types of Bullying in Cyberbully Movie

\section{Discussion}

\section{Types of Bullying}

The following below are the types of bullying that the researcher found in Cyberbully movie:

\section{Verbal Bullying}

\section{Data 1}

01:22:18-01:22:26

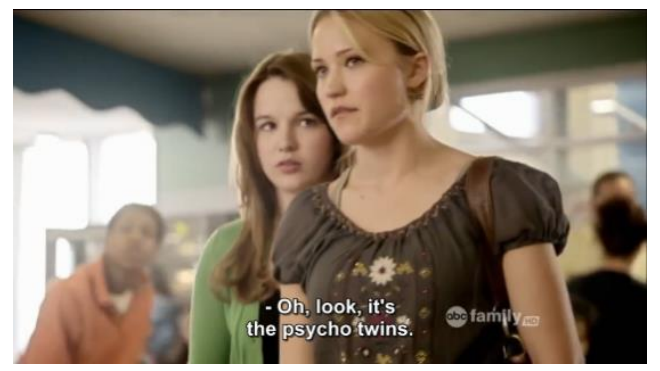

Lindsay $\quad$ : Oh, look, it's the psycho twins.

Samantha : Just ignore her.

This the type of bullying is shown in the scene where Taylor and Samantha are in the cafeteria, then meet Lindsay and her friends who are sitting in the cafeteria. Then Lindsay said "Oh, look, it's the psycho twins" to Taylor and Samantha when they walked beside Lindsay.

From the dialogue above, "Oh, look, it's the psycho twins" shows us verbal bullying. Because the meaning of psycho is a person who is mentally ill and who behave in a very strange violent way (Hornby, 2010). Which is a nickname joking intended for Taylor and Samantha. In fact, Taylor and Samantha are not psycho, it's just a nickname joking for them. According to Coloroso's theory, nickname joking is included in verbal bullying.

\section{Relational Bullying}

\section{Data 1}

00:40:34-00:41:02 


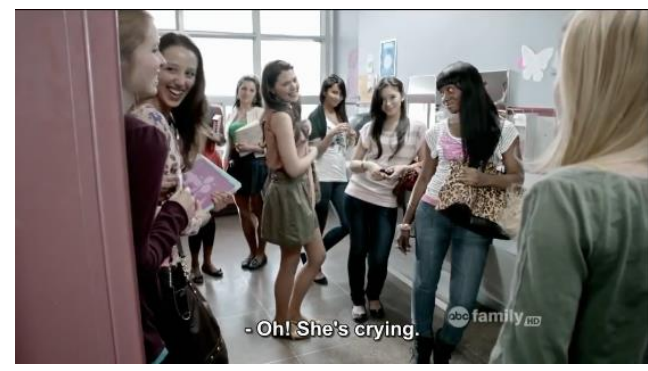

Lindsay : Oh! She's crying.

This the type of bullying is shown in the scene where Lindsay goes to the toilet and in the toilet there is Lindsay and her friends who immediately look aggressive and laugh at Taylor because Taylor looks like she wants to cry.

From the picture above shows us relational bullying because it can be seen that there are aggressive views and sneered laughter towards Taylor. Lindsay and her friends looked at Taylor with aggressive eyes and sneered laughter at Taylor because Taylor want to cry at that moment. According Coloroso's theory aggressive views and sneered laughter are included in relational bullying.

\section{Cyber Bullying}

\section{Data 1}

00:14:45-00:14:55

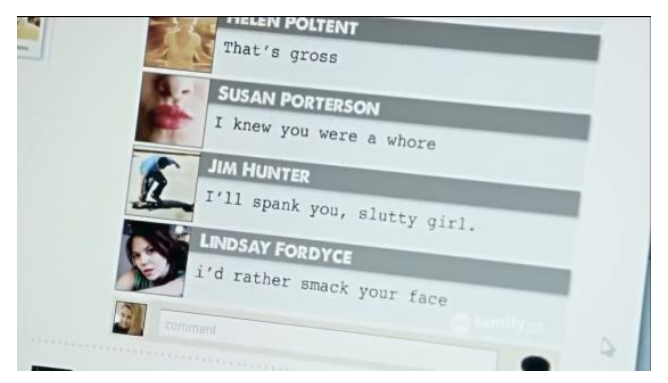

Helen : That's gross

Susan : I knew you were a whore

Jim : I'll spank you, slutty girl

Lindsay : I'd rather smack your face

This the type of bullying is shown in the scene where after Clicksters Taylor was hacked by Taylor's brother a lot of Taylor's school friends gave bad comments and gave a nickname joking to Taylor.

From the picture above is included in cyber bullying. Because they gave negative comments that led to the nickname joking on Taylor's social media, for example "I'll spank you, slutty girl" from the sentence slutty girl has shown Taylor a nickname joking. Slutty or slut is a woman who has many sexual partner (Hornby, 2010). This is included in cyber bullying because there is bullying in technology, internet and social media which is in accordance with Coloroso's theory. 


\section{Impacts of Bullying}

The following below are the impacts of bullying that the researcher found in Cyberbully movie:

\begin{tabular}{cclc}
\hline No. & Impacts of Bullying & \multicolumn{1}{c}{ Example } & Amount \\
\hline 1. & Effects on Feelings and & - Loneliness & 1 \\
& Behavior & & 1 \\
2. & Academic Impact & - Skipping School & 1 \\
3. & Psychological Impact & - Suicide & $\mathbf{3}$ \\
\hline \multicolumn{2}{c}{ Total } \\
\hline
\end{tabular}

Table 2 The Impacts of bullying in Cyberbully movie

\section{Effects on feelings and behavior}

Data 1

00:35:17-00:35:52

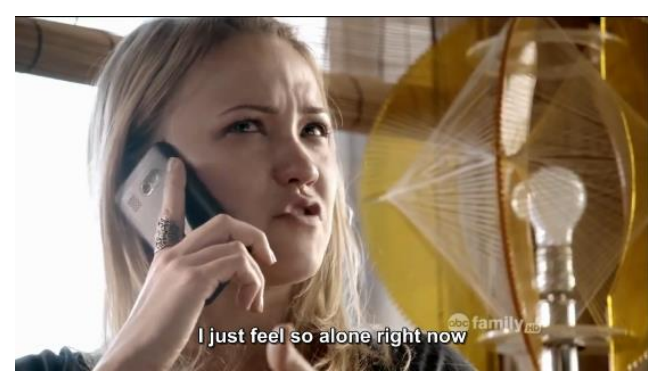

Taylor $\quad$ : Hi Dad! It's me Taylor. Um, I know you probably didn't pick up because you think I'm so mad at you, but, um. Ok, I take back what I said about never wanting to speak to you again. I just feel so alone right now and I don't know if you care or not, but, um just call me back.

This the impact of bullying is shown in the scene When Taylor calls his father to tell him about his situation. It is because Taylor no longer lives with his father because Taylor's parents are divorced, but the phone was not answered by Taylor's father, so Taylor sent a voice message to her father.

From the dialogue shows that there is an impact experienced by Taylor. That has an impact on effects on feelings and behavior, namely loneliness. Because when Taylor voice message her father, she said "I just feel so alone right now" from this sentence, indicating that Taylor felt alone in the situation at that time. According to Buckie's theory, loneliness is included in the effects on feelings and behavior.

\section{Academic Impact}

\section{Data 1}

00:34:25-00:34:31 


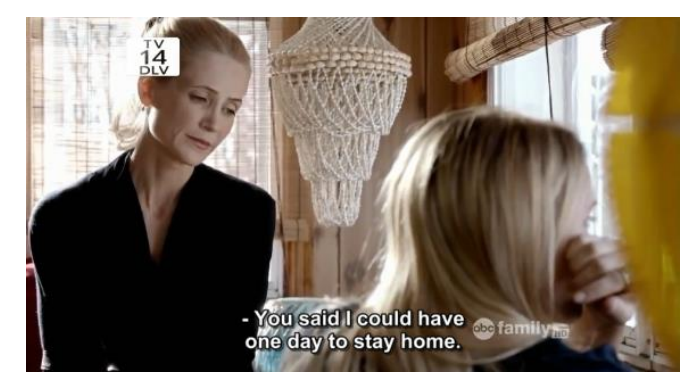

Mother : Did you change your mind about going to school?

Taylor $\quad$ : You said I could have one day to stay home

This the impact of bullying is shown in the scene when after false accusations about Taylor, Taylor decides to skip school. Taylor's mother a make sure to Taylor whether Taylor would change her mind and go to school. But Taylor still skipping school.

From the dialogue above, it can be seen that Taylor had an impact. This has an impact on the academic impact, namely skipping school. It is because Taylor's friends at school still to bully Taylor directly and on social media. The dialogue "You said I could have one day to stay home" show that Taylor ended up to skipping school for a while. According to SEJIWA's theory, skipping school is included in the academic impact.

\section{Psychological Impact}

\section{Data 1}

00:46:54-00:47:36

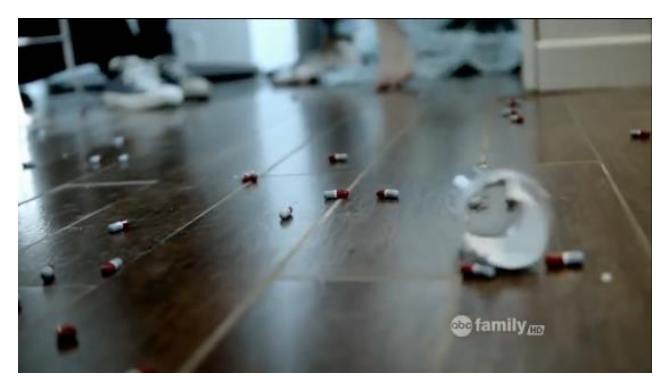

Taylor : What did you do?

Mother $\quad$ : Sit down, sit down, sit down Back up. It's ok. I got you. Baby it's ok

Samantha : Please

Taylor : I wanna die. No! I wanna die

This the impact of bullying is shown in the scene when Samantha sees Taylor's clarification video on Clicksters, then Samantha calls Taylor but Taylor doesn't pick up. Samantha immediately came to Taylor's house while calling Taylor's mother. When they arrived at Taylor's house, Samantha went to the toilet in Taylor's room and saw Taylor opening a bottle of medicine for a suicide. 
From the picture above shows that there is an impact experienced by Taylor and she said "I wanna die. No! I wanna die". That has an impact on psychological impact, namely suicide. Because people at school and on Taylor's social media still to bully Taylor. One time Taylor tried to suicide by taking a lot of medicine. But failed because Samantha came to Taylor's bathroom, which at that time Taylor was trying to open the medicine. According to SEJIWA's theory, suicide is included in the psychological impact.

\section{CONCLUSION}

This research are to find out the types of bullying that the character Taylor Hillridge receives in Cyberbully movie, based on Coloroso's theory and the impacts of bullying that the character Taylor Hillridge suffers in Cyberbully movie based on SEJIWA's theory and Buckie's theory. There are the types of bullying, researcher found: 6 data of verbal bullying, such as nickname joking, humiliation, false accusations, 2 data of relational bullying, such as sneered laughter, aggressive views and 10 data of cyber bullying, such as social media bullying. However, there are the impacts of bullying, researcher found: 1 datum of effects on feelings and behavior, such as loneliness, 1 datum of academic impact, such as skipping school and 1 datum of psychological impact, such as suicide.

\section{REFERENCE}

Al-Ma'ruf, A. I., \& Nugrahani, F. (2017). Pengkajian Sastra Teori dan Aplikasi. Surakarta: CV. Djiwa Amarta Press.

Bogdan, \& Taylor. (1975). Metodologi Penelitian Kualitatif. Bandung: Remadja Karya.

Buckie, C. (2013). Bullying \& Cyberbullying: What we need to know a reference for parents and guardians. Canada: Nova Scotia.

Coloroso, B. (2007). Stop Bullying. Jakarta: PT Serambi Ilmu Semesta.

Hornby, A. S. (2010). Oxford Advanced Learner's Dictionary. New York: Oxford University Press.

Irawanto, B. (1999). Film, Ideologi, dan Militer; Hagemoni Militer dalam Sinema Indonesia. Yogyakarta: Media Pressindo.

Mabruri, A. (2018). Produksi Program TV Drama Manajemen Produksi dan Penulisan Naskah. Jakarta: PT. Gramedia Widiasarana Indonesia.

Priyatna, A. (2010). Let's End Bullying: Memahami, Mencegah, dan Mengatasi Bullying. Jakarta: PT Alex Media Komputindo.

SEJIWA. (2008). Bullying: Mengatasi Kekerasan dan Lingkungan Anak. Jakarta: PT Grasindo.

Sobur, A. (2016). Semiotika Komunikasi. Bandung: PT Remaja Rosdakarya.

Sudjiman, P. (1990). Memahami Cerita Rekaan. Jakarta: Pustaka Jaya.

Surastina. (2018). Pengantar Teori Sastra. Yogyakarta: Elmantera.

Wiyani, N. A. (2014). Save Our Children From School Bullying. Jogjakarta: Ar-Ruzz Media.

http://sejiwa.org/bullying\%20a-z/ 